W. P. A. van Lammeren (Netherlands Ship Model Basin) was in the chair. Instruments for measuring fluctuating forces, pressures and velocities and others specially developed for new Admiralty large-scale test facilities were described, while one paper gave details of high-speed photographic methods (with pictures taken at rates of up to 1 million per second) designed for studies of individual bubbles in ultrasonic cavitation, which have a life-cycle, during which intense collapse pressures are generated, encompassed in $l \mu$ sec. A paper outlining the performance characteristics of a small experimental water tunnel led to a vigorous discussion of the virtues of re-absorption devices (inelegantly but widely known as resorbers) in large-scale cavitation testing rigs. Many new water tunnels, including a large new propeller tunnel to be built for the National Physical Laboratory, incorporate expensive resorbers, and the general consensus of opinion seemed to be that these are desirable provided sufficient money is available.

Even large test facilities for ship propellers and water turbines can only handle models which are small compared with their prototypes, and thus scaleeffect factors are of great importance in cavitation studies. The papers at the fourth session of the symposium, under Prof. J. W. Daily (Massachusetts Institute of Technology), dealt with this thorny problem, and the relative importance of the significant parameters, particularly the Froude, Reynolds and Weber numbers, was discussed. One paper gave some disturbing preliminary results from a series of geometrically similar model propellers, and another showed remarkable Admiralty photographs of propeller cavitation patterns taken during ship trials of a destroyer and other naval vessels. The following session, with Mr. F. S. Burt (Admiralty Research Laboratory) as chairman, was concerned with a related problem - the effects of cavitation on the hydrodynamic performance of foils. Valuable data on the properties of hydrofoils under super- cavitating conditions (when fully developed, steadystate cavities spring from the leading edge) were given in a group of papers and supplemented in the discussion. A pleasant, and valuable, interlude here was an excellently produced film, with full colour and sound, showing some of the pioneering work being done at the California Institute of Technology. Finally, the delegates turned their attention to the vexed question of cavitation damage, and the papers delivered at this session presented very different views on the mechanism of damage erosion, the upholders of the two schools of impingement attack and corrosion fatigue being in evidence. The qualities of cathodic protection as a damage inhibitor, and the role of gas in water as a damage 'cushion', were also argued. The damage potential of cavities of fixed type, shown to have a fiercely periodic nature with violent downstream collapse conditions, was also brought out; and if this session cannot claim to have resolved the opposed views, it certainly did much to clarify them. Mr. Eisenberg, chairman at this session, persuaded Prof. J. Ackeret (Zurich), a pioneer in this field, to remind the delegates of some highly pertinent effects of shock waves in causing damage, and in his own closing remarks commented that the programme of the symposium had clearly brought out the central problems for discussion. Dr. Allan, responding for the National Physical Laboratory, regretted that the delegates had had to remain almost silent on the problems of cavitation noise; but hoped that in spite of this the meetings would encourage further research which would extend our knowledge and control of cavitation phenomena. Dr. Allan felt that this research should not be organized on an internationally agreed programme, perhaps not even on a national basis, but that individual workers should pursue their own interests and meet at intervals to exchange views. This suggests that the first conference on cavitation problems will be followed by others.

A. Silverleaf

\title{
DEATH AND THE AFTER-LIFE
}

$\mathrm{T}$ HE general theme, "Disposal of the Dead, and Beliefs in an After-Life", was selected as the main part of the programme of Section $H$ (Anthropology and Archæology) at the recent Bristol meeting of the British Association, because experience had shown the need for a common topic about which anthropologists and archæologists desired each to hear what the others had to say, and the theme chosen provided scope for participation by nearly all elements in the section. With one or two exceptions, the papers were grouped in the sessions as indicated by the headings.

\section{From the Origin of Man to the Mesolithic Period}

The evidence from pre-Neolithic peoples was discussed in the opening session by Dr. Kenneth Oakley, Mr. Miles Burkitt and Dr. L. H. Wells. In his paper on "Earliest Evidence of Disposal of the Dead", Dr. Oakley remarked on the tendency, among gregarious non-human primates, for the dying animal to leave the sleeping-place of the troop. He then dealt with cannibalism, which was widespread before disposal of the dead by ceremonial or careful burial became regular. All the remains of Pekin man in the Choukoutien cave deposits are judged to be the debris of cannibal feasts. The bones of Neanderthalers in the Krapina cave appear to have been deliberately broken, and many were charred; the female skull from Ehringsdorf shows evidence of mortal blows; the breaking of the Steinheim skull was evidently deliberate, and all the eleven Solo (Ngandong, Java) skulls have their bases and facial bones missing as if broken for extraction of their brains. The base of the Neanderthal skull found within a ring of stones on the floor of the Goat's Cave in Monte Circeo has clearly had the foramen magnum enlarged for this purpose. Therefore, it appears that head-hunting and brain-eating were characteristic of these early periods.

Mr. Miles Burkitt then dealt with "Middle and Upper Palæolithic Burials". It was not only the 'old man' of the family, but also women and children who were carefully buried. At La Chapelle aux Saints, it is true, there was only one burial of a man in a sepulchral cave, with evidence that the interment had taken place with care and ceremony ; but at La Ferrassie the whole family were buried in what presumably had been their home, with care and possibly some sort of ritual, as the body of one of the children was covered by an artificially cupmarked stone. Other Mousterian burials are known. Whether the reason for this care for some of the 
dead was fear or love, or a belief in some sort of after-life, we can never know. The burying of implements and bones of animals with the dead would seem to suggest that the mourners thought the dead might need these at some time.

In Upper Palæolithic times we also have plenty of evidence for careful burial; and here, too, discoveries suggest that some sort of ceremony occurred at the interments. Cro-Magnon and Chancelade are sites to mention, as well as some burials at Mentone where the body of the male occurs laid out with his head on a stone pillow, and partly covered with pierced shells. The female was entirely covered with unpierced shells. In most cases ochre was sprinkled over the bodies-possibly imitating life-blood.

The practice of careful burial continued into Mesolithic times. Apart from elaborate burials, such as Ofnet (where, as Dr. Wells later mentioned, severed heads probably imply ritual head-hunting), there is plenty of evidence of simpler procedure but yet indicating careful burial-as at Hoëdic, Téviec, Nugem and Axpea.

Dr. L. H. Wells concluded the first session with a review of the pre-Neolithic evidence from Britain, and in the course of his paper described the Cheddar skeleton as the finest Upper Palæolithic cave-burial in Britain, and expressed the view that some of the skeletons from Aveline's Hole (Mendip) were definite burials. The Mesolithic population of Britain may well have been derived from Upper Palæolithic groups.

\section{Evidence from Living Primitive Peoples}

The funerary customs of living primitive races were discussed by Dr. R. M. Berndt, Dr. Jack Goody, Mr. G. W. B. Huntingford and Mr. Hitoshi Watanabe. Dr. Berndt being abroad, his paper on "Cannibalism in the Eastern Central Highlands of New Guinea" was read by Dr. Goody. Cannibalism was described as "a most nourishing and hygienic means of disposing of the dead", the practice of which is common and not abnormal in the area described. The Eastern Highlanders of New Guinea put much emphasis on warfare, and are somewhat careless of death. Behind this attitude, however, is a belief in an after-life, in reunion with the original creative beings, and eternal residence in some kind of spirit world, or alternatively in rebirth. The newly dead are considered to have much the same needs as the living, and when they appear to their kin in dreams, it is often to ask for food, warmth or fire.

Eating human flesh is not confined to members of one sex, nor is it restricted to eating one's own kin, or members of the same district or village. Men do not hesitate to eat the flesh of a female, or women that of a male, while an enemy is eaten just as readily as a member of one's own kin. People avoided eating victims of the dysentery epidemic which followed the Second World War. Human meat is regarded primarily as food, and not eaten to absorb the power or strength of the deceased.

Dr. Goody's paper was on "Death and Social Control among the Lo Dagaa of the Gold Coast". He expressed the belief that "the conflict between the mortality of the human body and the immortality of the body politic is resolved by the belief in a future life". Only situations of rapid social change can admit scepticism in this field. Lo Dagaa beliefs include punishments meted out by the Ferryman at the River of Death to debtors, witches, thieves, and to those who have refused legitimate requests. There are also the punishments inflicted in the Land of the Dead by the high god himself. The Lo Dagaa funerals are dual, consisting of : (i) the mortuary ceremony (disposal of the body), and (ii) subsequent ceremonies (connected with eschatological beliefs). Orientation of the body differs for men and women, and childless adults have a form of burial different from those who have had children. The temporary deposit of gravegoods is known among this tribe.

Mr. G. W. B. Huntingford spoke on "Nandi Beliefs in a Future Life". In common with many other East African tribes, the Nandi of Kenya rely on the hyæna to dispose of their dead. A hyæna must not be looked in the eyes in the daytime (according to the Nandi), because the spirit of a dead person may be looking through them. Every person is believed to have a shadow-soul which dies with him, and a heart-soul which passes with the body into a hyæna and finally enters the spirit-land underground. This spirit-land is considered to contain trees, grass, hills, water, sun and moon, as in this world. The spirits are believed to have cattle and grow wheat: yet there is the incompatible belief that they live on the goods provided by the living. Grave-goods placed with the dead are removed from the tomb after one day, to be re-used by the living.

The final paper on living peoples was given by Mr. Watanabe on "Disposal of the Dead by the Ainu of Japan". According to the Ainu, the dead are met in the underworld by a watch-dog; from the underworld the fire-god sends the good dead to the (upstream) village of deities, and the bad dead to the (downstream) wet underworld. The welfare of the dead depends partly on correct observance of rituals and taboos by the living, who practise them carefully, since good spirits can confer punishments and bless. ings on the living. The corpse is dressed in clothes which are worn inside-out (an excellent example of reversal of procedure for the dead, met with also in parts of Oceania). Food is offered first to the firegod, then to the dead, and finally it is eaten by the mourners. After the funeral feast, the corpse is extended with head upstream. All the grave-goods are ceremonially broken to release their spirits to accompany the dead to the after-life. Both tomb and grave-goods are covered with magical twigs and plants to keep away evil spirits. Post-funerary rites are performed after the dead are considered to have reached their destination. (It is hoped that $\mathrm{Mr}$. Watanabe's paper will be published in full in The Advancement of Science.)

\section{Evidence from American Archæology}

Evidence from South and Central American archæology was outlined in papers by Dr. G. H. S. Bushnell and Mr. Adrian Digby. Dr. Bushnell, dealing with ancient Peru, referred to the two main traditions of burial, both dating back at least to the formative period in the first millennium B.c. The first (north coast) was of recumbent burials, at first generally flexed but sometimes extended, and later almost without exception extended. A gold plaque in the mouth is frequent, and bamboo tubes for food offerings, extending to the surface of the ground, occur but are rare. The second tradition (south coast and southern highlands) had bodies seated in a crouched posture and generally wrapped in textiles to form a bundle, which may have a false face. The richer burials in both areas were elaborate, the 
southern mummies being wrapped in many layer's of textiles, some richly decorated. The Tiahuanaco expansion spread the southern tradition over the whole coast and it prevailed everywhere until the Spanish conquest.

There seems to have been at all times a belief in the continued being of the body or at least of the bones. In Inca times it was believed that nobles and good commoners went to a happier life with the sun, and bad commoners went to hunger and misery within the earth; but the mummies were treated with the consideration appropriate to a living person. This points to a belief in a soul apart from the mummy.

Burial and the after-life among the Maya of southeast Mexico and adjoining areas between about 100 B.C. and A.D. 900 were considered by Mr. Adrian Digby. He referred to their elaborate ceremonial centres embodying temples, courts and pyramids, in some of which burials have been found. For example, at the bottom of the pyramid below the Temple of Inscriptions at Palenque in Mexico, there was a sarcophagus decorated with the design of a tree symbolizing life and rebirth, resembling that shown springing from a wounded victim on a pre-Columbian Maya manuscript. Belief in immortality is suggested by certain practices, such as modelling the features of the dead in bitumen on the skull ; deposit of red ochre with some important burials; deposit of jadeite beads, perhaps to serve as money in the after-life; and occasional ceremonial killing of vessels placed with the dead.

\section{Evidence from Egyptian Archæology}

Dr. Margaret Murray, doyen of Egyptologists, in an address memorable for its clarity of exposition, confined her review of Egyptian funerary evidence to the prehistoric and predynastic material. The Badarian burials were single, flexed as in sleep, facing the west-the Land of the Dead. The Amratian burials were communal, contracted, and again faced the west. A few exceptions may have belonged to a special cult or been foreigners. The body was sometimes dismembered, and in certain instances the head was removed and either a pot or an ostrich egg substituted. In other instances the head was preserved on its own. Gerzean burials tended to be single, contracted, and in deep graves. Lastly, those of the Semainean culture were usually single and contracted, often in wooden coffins. The bones were sometimes disarranged and piled in square heaps. A skull cult, perhaps involving scooping out the brain, was not unknown in predynastic Egypt and continued in later times.

\section{Evidence from British Archæology}

The remaining sessions were devoted to a consideration of the British evidence from the Neolithic period almost to the present day. Dr. H. N. Savory drew upon some recent excavations in his paper on "Communal and Separate Burial in Neolithic Britain"-a paper which covered two distinct though partly overlapping cultures between 2000 and 1500 B.c. Dealing mainly with the evidence from the south-west, he stressed the rarity of articulated corpses in long barrows, caused probably by transfer from a temporary deposit elsewhere. Deliberate breaking and rearrangement of bones suggested that fear of haunting played a part in the cult. In separate burials, solicitude for the after-life is more clearly indicated by richer grave-goods, food offerings and occasional ritual breaking of the objects rather than the bodies. The encircling wall or ditch of the round barrow defined the ceremonial precinct and may be related to 'henge' monuments, although the latter were not primarily sepulchral.

"Inhumation and Cremation in the British Bronze Age, and Related Beliefs" were handled by Mr. L. V. Grinsell against the background of the less fragmentary evidence from the Agcan, Scandinavia, Brittany and elsewhere. He gave instances of occasional substitution for grave-gifts of representations of them, and of ceremonial funerary breakings. The grave-goods we find when barrows are opened are only the more durable of those originally placed with the dead, and it is only in accidental circumstances that the perishable objects are preserved-as in the tombs of the Altai region in western Siberia, where preservation was due to freezing.

In describing "Beliefs in the After-Life in Iron Age and Roman Britain", Prof. I. A. Richmond explained how "the classical world impinged upon the prehistoric, and studied the barbarian world for its own sake while tolerating native custom within its own wide borders". This renders a separation between Iron Age and Romano-British beliefs almost unreal. Wine-filled tombs of Iron Age chieftains in East Anglia match the beliefs of Trimalchio "Let me enjoy [the funeral wine] now !"), while Mommsen's Lingonian chief, cremated with his hunting gear, would have understood the hunting scenes on tombstones of later Pietland. Higher beliefs are reflected in Plutarch's traditions from the Western Isles or by St. Cuthbert's vision of Aidan's soul. In Roman Britain, tombstones portraying daily life reflect belief in survival of a personality thus recorded, as does the "Agricola". Cavalry tombstones of victory over barbarians have more in common with Rhineland monuments commemorating victory over death. The funeral banquet refers both to after-life and ancestor. worship. As subsidiary decoration, sphinxes and lions typify death, pine-cones immortality, vines and amorini the Dionysiac mysteries. The soul's journey to the Blessed Isles is suggested by Tritons or dolphins.

Disposal changed from almost universal cremation to burial, less for economic reasons than because of growing belief in individual survival. Special care for the corpse is represented by the gypsum-filled coffins at York, while the Dionysiac idea of death as sleep is evoked at Chester by the figure of a sleoping child.

Dr. H. R. E. Davidson followed with an account of the funeral customs of the Anglo-Saxons, "the first people in the British Isles whose funeral practices can be studied in the light of their literature". Archæologically, nearly all the earlier practices recur in this period: cremation, partial cremation, ritual fires, food offerings, funeral feasts, mutilation of the body, real and symbolic grave-goods, animal sacrifice, ship-funerals, etc. According to Snorre Sturlason, the higher the smoke from the pyre, the more lofty the position of the dead in heaven. There is evidence for ritual fires with inhumations as well as cremations. The body was often beheaded and may have been mutilated in other ways. Broken grave-goods occasionally occur.

The period from Anglo-Saxon times to the present day was covered by Miss Violet Alford and $\mathrm{Mr}$. Grinsell. In her paper on "Dance and Song in con- 
nection with Funerary Rites", Miss Alford mentioned the continuance of pleureuses in the Pyrenees, Mexico, Co. Kerry and elsewhere, and referred to the 'wakes' at funerals in the British Isles. Funeral dances were usually the current regional dancesjigs and reels in Ireland, reels and country dances in Scotland. Folk memories of barrow-burials live in folk-song and ballad. Denmark shows examples of a son obtaining a magie sword from his father's barrow, and the visit of 'royal maidens' to dead men in their 'earth-house'. "The Unquiet Grave", a well-known English folk-song, recounts the visit of the dead man to his sweetheart, who is disturbing his rest by her excessive grief.

"The Survival and Recurrence of Primitive Funerary Beliefs and Customs in Recent Times" was the title of the concluding paper given by $\mathrm{Mr}$. Grinsell, who directed attention to the occasional recurrence of ceremonial breaking of grave-objects at funerals in the Agean and even in Britain; the placing of coins in the mouth or hand of the dead; and the placing of white (generally quartz) pebbles on graves. Shakespeare's reference ("Hamlet", Act V, Sc. i) to the placing of "shards, flints, and pebbles" on the grave of a suicide suggests the survival of pre-Christian practices in such instances.

In an earlier paper which was not actually part of the general theme, Mr. L. Biek, of the Ministry of Works Archæological Laboratory, described the development of scientific techniques for obtaining evidence from burials, including the X-ray examination of a cinerary urn and its contents ; examination of bronze implements to decide whether they had passed the funeral pyre ; and study of 'silhouettes' of inhumations which have otherwise vanished.

A special exhibit to illustrate some main aspects of the theme was arranged at the Bristol City Museum, the aspects chosen being the ceremonial breaking of grave-goods at funerals; food offerings to the dead; the journey to the after-life (including the part played by the Ferryman of the Dead) ; the location and nature of the after-life; and the various methods adopted for the treatment of the dead.

The programme was concluded by Prof. E. O. James, who in his summing up indicated the change in emphasis from 'disposal of the dead' to 'beliefs in an after-life' from Upper Palæolithic times onwards. There is much archæological and anthropological evidence for belief in human survival; but the belief in immortality tends to involve more advanced philosophical concepts.

The results of the programme were felt to be eminently satisfactory. A full or large attendance was maintained throughout, and the percentage of younger people at the sessions was larger than for some years. Of the fifteen speakers present, eight attended all the sessions, three about half, and the remaining four came mainly to deliver their own papers, either breaking their holidays or in the midst of heavy commitments. Not a few of the audience came from other sections ; but the most noteworthy result was the large number of archæologists and anthropologists whose minds became enriched by hearing the papers, and this applied both to the lecturers and to members of the audience.

I am grateful to all the speakers who kindly provided summaries of their papers, which have been used (together with my own notes) in preparing this account.
L. V. GRINSELI

\section{MANCHESTER COLLEGE OF TECHNOLOGY GRANT OF A CHARTER}

\section{By DR. B. V. BOWDEN Principal}

$\mathrm{T}$ HE recent grant of a Charter to the Manchester College of Technology marks another important stage in the development of the College, which traces its history back to a Mechanics Institute founded in 1824 by eleven far-sighted Manchester business men, who each contributed $£ 634$ for the purpose. By 1905 it had acquired such a reputation at home and abroad that the University of Manchester created a Faculty of Technology which was incorporated in the College.

Thus for the past fifty years the College has discharged two quite separate and vitally important functions. It has trained full-time university students for university degrees, and it has also trained large numbers of full-time and part-time students in a variety of subjects which lead to qualifications other than degrees. This interesting association of university and non-university work will continue under the new constitution. The College will still be part of the University of Manchester, from which it derives so much of its academic strength. The standard of non-university work will be constantly raised by the elimination of the more elementary studies. Courses for Higher National Certificates will still be provided; but the most important progress in this section will be in the provision of part-time or short full-time courses of postgraduate or refresher type. By this means the developments which take place so rapidly in technology will be brought to the notice of engineers and scientists engaged in industry.

No other institution in Britain has quite the same association of university and non-university work, an association of the greatest importance in meeting the needs of industry for technologists of varied training and background.

The College has always been fortunate in the support which it has received from industry, and there are already signs that such support will be forthcoming on an even greater scale under the new regime. In return, the College will strive to serve industry by making available specialized equipment, by consultation with members of the staff on scientific and technical problems as well as by training personnel.

Situated in the heart of the most intensely industrialized area in the world, the College must play an important part in providing the increased number of highly qualified scientists and technologists essential for the national welfare. To achieve this purpose, further expansion will be necessary-expansion in 